\title{
Ukuran Perusahaan Memoderasi Pengaruh Capital Intensity dan Profitabilitas Terhadap Agresivitas Pajak
}

\author{
Agung Budi Utomo ${ }^{1}$, Giawan Nur Fitria ${ }^{2 *}$ \\ 1, 2Universitas Mercu Buana \\ 1agungbudut101@gmail.com, 22giawan.nur@mercubuana.ac.id \\ *Penulis Korespondensi
}

\begin{abstract}
The research aims to determine the influence of capital intensity and profitability on tax aggressiveness using the company size as moderation variables. The research object is a mining company listed on the Indonesia Stock Exchange (IDX) from 2016 to 2018. The number of companies sampled in this research was 25 companies with 3 years of observation time over selected with purposive sampling techniques. The data analysis used statistical analysis in the form of multiple linear regression tests. This study showed that simultaneously the variable capital intensity, profitability and size of the company affected the tax aggressiveness. Partial capital intensity and company size have a negative effect on tax aggressiveness, while the profitability has no effect on tax aggressiveness. Otherwise, based on the moderated regression analysis (MRA) test, the company size variable can moderate the influence of capital intensity on the tax aggressiveness. Size can not moderate the influence of profitability on the tax aggressiveness.
\end{abstract}

Keywords: capital intensity, profitability, company size, tax aggressiveness, mining company

\begin{abstract}
Abstrak
Penelitian ini bertujuan untuk mengetahui pengaruh intensitas modal dan profitabilitas terhadap agresivitas pajak dengan menggunakan ukuran perusahaan sebagai variabel moderasi. Objek penelitian adalah perusahaan pertambangan yang terdaftar di Bursa Efek Indonesia (BEI) dari tahun 2016 sampai dengan 2018. Jumlah perusahaan yang dijadikan sampel dalam penelitian ini adalah 25 perusahaan dengan waktu observasi selama 3 tahun dipilih dengan teknik purposive sampling. Analisis data menggunakan analisis statistik berupa uji regresi linier berganda. Penelitian ini menunjukkan bahwa secara simultan variabel intensitas modal, profitabilitas dan ukuran perusahaan berpengaruh terhadap agresivitas pajak. Secara parsial, intensitas modal dan ukuran perusahaan berpengaruh negatif terhadap agresivitas pajak, sedangkan profitabilitas tidak berpengaruh terhadap agresivitas pajak. Sedangkan berdasarkan uji moderated regression analysis (MRA), variabel ukuran perusahaan dapat memoderasi pengaruh intensitas modal terhadap agresivitas pajak. Ukuran perusahaan tidak dapat memoderasi pengaruh profitabilitas terhadap agresivitas pajak.
\end{abstract}

Kata kunci: capital intensity, profitability, company size, tax aggressiveness, mining company

\section{Cara Mengutip:}

Utomo, A.B., Fitria, G. N. (2020). Ukuran Perusahaan Memoderasi Pengaruh Capital Intensity dan Profitabilitas Terhadap Agresivitas Pajak. Esensi: Jurnal Bisnis dan Manajemen. Vol. 10 (2): 231-246. DOI: https://doi.org/10.15408/ess.v10i2.18800 


\section{PENDAHULUAN}

Perusahaan merupakan salah satu wajib pajak yang memberikan kontribusi penerimaan pajak terbesar bagi penerimaan pajak negara. Namun, dalam prakteknya, tujuan dari pemerintah tersebut tidak mendapat sambutan yang baik dari perusahaan. Tidak sedikit perusahaan yang melakukan perencanaan pajak (tax planning) dengan tujuan untuk meminimalisasi pajak yang harus dibayar perusahaan. Pembayaran pajak yang sesuai dengan ketentuan tentunya akan bertentangan dengan tujuan utama perusahaan, yaitu memaksimalkan keuntungan atau laba, sehingga perusahaan berusaha untuk meminimalkan biaya pajak yang ditanggungnya. Cara yang dilakukan oleh perusahaan antara lain dengan tax planning atau dengan agresivitas pajak.

Belum optimalnya realisasi penerimaan pajak di Indonesia menjadi salah satu point penting yang harus diperhatikan pemerintah untuk dapat memaksimalkan devisa negara dari sektor pajak. Meskipun dari tabel tersebut menunjukan bahwa adanya peningkatan presentase pencapaian realisasi perpajakan dari tahun ke tahun, namun hasil tersebut masih belum maksimal. Salah satu penyebab belum optimalnya penerimaan pajak antara lain adalah adanya kegiatan agresivitas pajak yang dilakukan wajib pajak, yang salah satunya adalah melakukan penghindaran pajak.

Pada tahun 2019, mencuat kasus yang cukup menjadi sorotan publik, setelah laporan dari Global Witness yang memuat dugaan adanya penghindaran pajak yang dilakukan oleh PT. Adaro Energy Tbk. untuk menghindari pajak di Indonesia. Salah satu perusahaan batu bara terbesar di Indonesia tersebut dikabarkan telah mengalihkan keuntungan dari batu bara yang di tambang di Indonesia (Liputan6.com, 2019). Adaro disebut melakukan penghindaran pajak dengan memanfaatkan tindakan transfer pricing melalui anak perusahaan nya yang berdomisili di Singapura, yaitu Coaltrade Services International. Dari upaya yang diduga telah dilakukan sejak tahun 2009 hingga 2017 tersebut, menyebabkan PT. Adaro Energy Tbk dapat membayar pajak sebesar US\$ 125 juta atau Rp. 1,75 triliun (kurs Rp. 14.000) lebih rendah dari yang seharusnya dibayarkan di Indonesia. Sedangkan untuk negara Indonesia sendiri dengan nilai yang harus dibayarkan tersebut seharusnya dapat dimanfaatkan untuk peningkatan kesejahteraan maupun untuk kegiatan pembangunan nasional.

Pengamat perpajakan Yustinus Prastowo menjelaskan wajib pajak termasuk badan usaha atau perusahaan lazim melakukan perencanaan pajak, namun upaya tersebut sering muncul untuk mengakali aturan pajak. Ia menjelaskan dalam konteks perpajakan siapapun memiliki kesempatan dan peluang dalam melakukan tax planning yang pada akhirnya berujung pada penghindaran pajak. Pemerintah Indonesia melalui Sri Mulyani Indrawati selaku Menteri Keuangan menyatakan bahwa pihaknya masih mencermati indikasi penghindaran pajak yang dilakukan oleh PT. Adaro Energy Tbk tersebut (Finance.detik.com, 2019).

Hal tersebut semakin menegaskan bahwa fenomena penghindaran pajak maupun agresivitas pajak lainnya di Indonesia masih marak terjadi di berbagai sektor usaha, seperti sektor pertambangan, manufaktur, perikanan, perkebunan, properti dan beberapa sektor lainnya. Banyak upaya dengan berbagai macam cara dari wajib pajak untuk melakukan agresivitas pajak tersebut. Oleh sebab itu, penelitian ini ingin mencari tahu faktor-faktor apa saja yang menyebabkan terjadinya tindakan pajak agresif di Indonesia. 
Menurut (Margaret, Lynch, Rego, \& Rego, 2009) tindakan pajak agresif atau agresivitas pajak adalah suatu tindakan yang bertujuan untuk merekayasa laba kena pajak perusahaan melalui perencanaan pajak, baik menggunakan cara yang legal (tax avoidance) atau ilegal (tax evasion). Agresivitas pajak dapat diukur dengan berbagai cara, yaitu dengan menggunakan Effective Tax Rate (ETR), Book Tax Difference (BTD), Residual Tax Difference (RTC), dan Cash Effective Tax Rate (CETR).

Agresivitas pajak adalah suatu tindakan yang ditujukan untuk menurunkan laba kena pajak melalui perencanaan pajak baik menggunakan carayang tergolong atau tidak tergolong tax evasion (Richardson, Taylor, \& Lanis, 2013). Menurut (Ridha \& Martani, 2014) agresivitas pajak merupakan aktivitas penghematan yang sesuai dengan peraturan yang berlaku. Menurut (Suprasto \& Suprimarini, 2017) Agresivitas Pajak adalah tindakan manajerial dengan tujuan meminimalkan bahkan menghilangkan kewajiban pajak perusahaan. Menurut Hlaing (2012) dalam Prameswari (2017) agresivitas pajak adalah suatu kegiatan perencanaan pajak yang dilakukan oleh perusahaan dimana memiliki tujuan untuk mengurangi beban pajak yang dibayar dalam periode tersebut yang akan berakibat turunnya tarif pajak efektif. Sedangkan (Crocker \& Slemrod, 2004) berpendapat bahwa agresivitas pajak merupakan aktivitas spesifik yang tujuan utamanya meminimalkan biaya pajak perusahaan. Para peneliti sebelumnya telah meneliti beberapa faktor yang mempengaruhi wajib pajak untuk melakukan agresivitas pajak, diantaranya adalah intensitas modal (Capital Intensity), profitabilitas dan ukuran perusahaan.

Intensitas modal (Capital Intensity) adalah aktivitas investasi yang dilakukan perusahaan yang dikaitkan dengan investasi dalam bentuk aset tetap. Kepemilikan asset tetap yang tinggi akan menimbulkan beban penyusutan yang tinggi pula, sehingga akan berdampak pada laba perusahaan yang semakin mengecil akibat adanya beban penyusutan tersebut. Jadi dengan semakin tinggi nya jumlah aset yang dimiliki perusahaan akan mendorong perusahaan untuk melakukan tindakan agresivitas pajak. Berdasarkan penelitian terdahulu yang dilakukan oleh (Fajar Adisamartha \& Noviari, 2015), (Nugraha \& Meiranto, 2015) dan (Novitasari, Vince, \& Silfi, 2017) menyatakan bahwa Intensitas Aset Tetap tidak berpengaruh pada tingkat agresivitas wajib pajak badan. Artinya perusahaan dengan tingkat aset tetap tinggi tidak mampu memanfaatkan beban depresiasi untuk mengurangi laba bersih. Aset tetap digunakan untuk membantu operasional perusahaan, penggunaan aset tetap tersebut mampu meningkatkan operasional perusahaan dan meningkatkan laba bersih lebih tinggi dibandingkan beban depresiasi yang dibebankan pada aset tetap. Sedangkan menurut penelitian (Andhari, P. A. S., \& Sukartha, 2017) yang dilakukan pada perusahaan sektor pertambangan yang listing di BEI tahun 2013-2015 menyatakan bahwa Capital Intensity berpengaruh positif pada agresivitas pajak perusahaan.

Penelitian lain yang dilakukan untuk mengetahui faktor-faktor yang mendorong wajib pajak untuk melakukan agresivitas pajak adalah dengan memfokuskan pada kinerja keuangan perusahaan. Salah satu alat pengukuran kinerja keuangan perusahaan adalah profitabilitas. Menurut Kasmir (2018:196) Profitabilitas digunakan untuk menilai kemampuan suatu perusahaan dalam menghasilkan laba selama periode tertentu.

(Susanto, Yanti, \& Viriany, 2018), (Andhari, P. A. S., \& Sukartha, 2017), (Sufia, Riswandari, \& Mulia, 2018), (Natalya, 2018) \& (Sufia et al., 2018) dalam penelitiannya 
menyatakan bahwa profitabilitas memiliki pengaruh yang signifikan terhadap tindakan agresivitas pajak. Hal ini menunjukan dengan semakin tingginya profitabilitas, perusahaan akan cenderung melakukan agresivitas pajak untuk dapat mengurangi beban pajak yang harus dibayarkannya.

Hasil berbeda didapatkan oleh (Isnanto, Si, \& Ab, 2019), (Mustika, Ratnawati, \& Silfi, 2017), (Fachrina Yuliana, 2018) mereka menyimpulkan bahwa profitabilitas tidak berpengaruh signifikan terhadap agresivitas pajak. Hal ini disebabkan karena dengan profitabilitas perusahaan yang tinggi akan menunjukan bahwa kinerja perusahaan tersebut baik. Sehingga perusahaan memilih untuk tidak melakukan agresivitas pajak dengan menurunkan pre-tax income (laba sebelum pajak penghasilan), karena hal itu akan menurunkan profitabilitas perusahaan yang mengindikasikan kinerja perusahaan kurang baik.

Faktor lain yang mempengaruhi agresivitas pajak adalah ukuran perusahaan. Menurut Hartono (2015:254) besar kecilnya perusahaan dapat diukur dengan total aktiva besar harta perusahaan dengan menggunakan penghitungan nilai logaritma total aktiva. Secara umum ukuran perusahaan dibagi menjadi 3 kelompok yaitu perusahaan besar, sedang dan kecil. Penelitian mengenai pengaruh ukuran perusahaan terhadap agresivitas pajak pernah dilakukan oleh (Tiaras \& Wijaya, 2017), (Fachrina Yuliana, 2018), (Yanti \& Hartono, 2019) mereka menyimpulkan bahwa ukuran perusahaan memiliki pengaruh terhadap agresivitas pajak. Hal ini disebabkan karena perusahaan yang besar dianggap lebih mampu menggunakan segala sumber daya yang dimilikinya untuk membuat suatu perencanaan pajak dengan baik.

Banyaknya penelitian terdahulu yang menjelaskan bahwa ukuran perusahaan berpengaruh secara signifikan terhadap agresivitas pajak. Penelitian menggunakan ukuran perusahaan sebagai variable moderasi.

Menurut (Novitasari et al., 2017) Intensitas modal atau capital intensity adalah aktivitas investasi yang dilakukan perusahaan yang dikaitkan dengan investasi dalam bentuk aset tetap (modal). Dengan semakin besar aset tetap yang dimiliki perusahaan mengakibatkan depresiasi yang besar juga sehingga mengakibatkan jumlah penghasilan kena pajak yang harus dibayarkannya berkurang. Berdasarkan penelitian yang dilakukan oleh (Andhari, P. A. S., \& Sukartha, 2017) menunjukan bahwa variabel capital intensity atau intensitas modal memiliki pengaruh positif terhadap agresivitas pajak. Penelitian tersebut sejalan dengan penelitian yang dilakukan oleh (Nugraha \& Meiranto, 2015), (Natalya, 2018), (Isnanto, Si, $\& \mathrm{Ab}, 2019)$.

$\mathrm{H}_{1}$ : Capital Intensity berpengaruh terhadap Agresivitas Pajak

Berdasarkan Teori Agensi, dalam kepentingan untuk meyakinkan investor untuk menanamkan modalnya, profitabilitas yang diproksikan dengan ROA yang tinggi merupakan salah satu indikator penting atas suatu kinerja sebuah perusahaan. Dengan ROA yang tinggi akan membuat investor tertarik menanamkan modalnya dengan harapan perusahaan mampu memberikan tingkat pengembalian yang tinggi atas modal tersebut. Semakin tinggi tingkat profitabilitas sebuah perusahaan, maka akan semakin besar beban pajak yang harus dibayarkannya. Hal tersebut disebabkan karena besaran beban pajak diperhitungkan berdasarkan besarnya penghasilan yang didapatkan oleh perusahaan. Dengan beban pajak yang tinggi mengakibatkan perusahaan akan berusaha untuk melakukan tindakan 
agresivitas pajak. Sehingga perusahaan yang memiliki profitabilitas yang tinggi cenderung akan melakukan agresivitas pajak yang diukur dengan nilai ETR. Nilai ETR yang semakin rendah mengindikasikan perusahaan melakukan tindakan agresivitas pajak. Pernyataan tersebut didukung oleh penelitian yang dilakukan oleh (Andhari, P. A. S., \& Sukartha, 2017), (Susanto, Yanti, \& Viriany, 2018) \& (Natalya, 2018) yang menyatakan bahwa profitabilitas berpengaruh terhadap agresivitas pajak. Perusahaan yang lebih profitable dan efisien pada sumber dayanya bisa mendapatkan tarif pajak efektif yang lebih rendah, sebab perusahaan dapat menggunakan sumber dayanya untuk memanfaatkan insentif pajak dan melakukan pengelolaan perencanaan pajaknya dengan baik sehingga dapat menurunkan kewajiban pajak efektifnya.

$\mathrm{H}_{2}$ : Profitabilitas berpengaruh terhadap Agresivitas Pajak

Ukuran perusahaan adalah skala atau nilai yang dapat mengklasifikasikan suatu perusahaan ke dalam kategori besar atau kecil berdasarkan total Asset. Perusahaan yang termasuk dalam perusahaan besar cenderung memiliki sumber daya yang lebih besar melakukan pengelolaan pajak karena adanya biaya yang melekat pada sumber daya tersebut dibandingkan dengan perusahaan yang lebih kecil. Aset merupakan sumber daya perusahaan yang disinyalir dapat dimanfaatkan perusahaan dalam tindakan agresivitas pajak, karena adanya biaya yang melekat pada aset tersebut.

Pernyataan tersebut didukung oleh penelitian yang dilakukan oleh (Fachrina Yuliana, 2018), (Yanti \& Hartono, 2019), \&(Tiaras \& Wijaya, 2017) yang menyatakan bahwa ukuran perusahaan berpengaruhterhadap agresivitas pajak. Hal ini menunjukkan bahwa semakin besar ukuran perusahaan akan menurunkan tingkat agresivitas pajak dan memiliki pengaruh yang signifikan. Tingginya biaya penyusutan yang ditanggung perusahaan atas kepemilikan aset yang ada menyebabkan rendahnya laba perusahaan pada periode tersebut. Rendahnya laba perusahaan akan mengakibatkan rendahnya beban pajak yang harus ditanggung perusahaan pada periode tersebut, sehingga perusahaan mengurangi tindakan agresivitas pajaknya karena beban pajak

$\mathrm{H}_{3}$ : Ukuran Perusahaan berpengaruh terhadap Agresivitas Pajak

Semakin besar sebuah perusahaan maka intensitas modal dan aset yang dimilikinya akan semakin besar. Dengan adanya sumber daya yang besar tersebut dapat dimanfaatkan perusahaan untuk mengurangi beban pajaknya. Namun dengan semakin besarnya ukuran sebuah perusahaan yang ditunjukan dari nilai aset yang dimilikinya maka, perusahaan tersebut akan mendapatkan perhatian lebih dari otoritas maupun investor. Oleh sebab itu, semakin besar ukuran perusahaan dengan intensitas modal yang juga tinggi cenderung akan mengurangi tindakan agresivitas pajaknya.

Pernyataan tersebut didukung oleh penelitian yang dilakukan oleh (Tiaras \& Wijaya, 2017), (Fachrina Yuliana, 2018) dan (Yanti \& Hartono, 2019) yang menyatakan bahwa ukuran perusahaan berpengaruh signifikan terhadap agresivitas pajak.

$\mathrm{H}_{4}$ : Ukuran Perusahaan memperkuat Pengaruh Capital Intensity terhadap Agresivitas Pajak

Besarnya profitabilitas yang dimiliki sebuah perusahaan maka beban pajak yang harus dibayarkannya juga akan semakin besar. Hal tersebut disebabkan karena besaran beban pajak diperhitungkan berdasarkan besarnya penghasilan yang didapatkan oleh 
perusahaan. Dengan beban pajak yang tinggi mengakibatkan perusahaan akan berusaha untuk melakukan tindakan agresivitas pajak. Namun berdasarkan teori biaya politik dimana pada teori tersebut dijelaskan bahwa dengan adanya perhatian pemerintah pada perusahaan besar maka tindakan agresivitas pajak akan terminimalisir. Dengan demikian semakin besarnya ukuran sebuah perusahaan yang ditunjukan dari nilai aset yang dimilikinya maka perusahaan tersebut akan mendapatkan perhatian lebih dari otoritas maupun investor. Oleh sebab itu, semakin besar ukuran perusahaan dengan tingkat profitabilitasnya cenderung akan mengurangi tindakan agresivitas pajaknya.

Pernyataan tersebut didukung oleh penelitian yang dilakukan oleh (Tiaras \& Wijaya, 2017), (Fachrina Yuliana, 2018) dan (Yanti \& Hartono, 2019) yang menyatakan bahwa ukuran perusahaan berpengaruh signifikan terhadap agresivitas pajak.

$\mathrm{H}_{5}$ : Ukuran Perusahaan memperkuat Pengaruh Profitabilitas terhadap Agresivitas Pajak

Tujuan penelian ini ingin melihat apakah pengaruh capital intensity dan profitabilitas terhadap agresivitas pajak dapat diperkuat oleh Ukuran Perusahaan atau tidak. Hasil penelitian ini memberikan kontribusi sebagai tambahan literatur terkait dengan agresivitas pajak. Berdasarkan fenomena penghindaran pajak dan agresivitas pajak di Indonesia serta adanya inkonsistensi terhadap hasil penelitian terdahulu, maka penulis ingin melakukan pengujian kembali untuk mengetahui faktor-faktor apa saja yang mempengaruhi tindakan agresivitas pajak.

\section{METODE}

Populasi yang akan menjadi pengamatan dalam penelitian ini adalah perusahaan pertambangan yang terdaftar di Bursa Efek Indonesia pada tahun 2016-2018. Pemilihan sampel pada penelitian ini menggunakan metode purposive sampling. Data yang digunakan dalam penelitian ini adalah data sekunder dengan metode kuantitatif yang mengacu pada informasi yang dikumpulkan dari sumber yang telah ada. Data ini berupa laporan keuangan perusahaan sektor pertambangan yang dipublikasikan di Bursa Efek Indonesia pada periode 2016-2018. Sumber data tersebut berasal dari Bursa Efek Indonesia melalui website $w w w$. idx.co.id.

Tahapan dalam pengelolaan data dalam openelitian menggunakan bantuan program MS Excel dan SPSS versi 25. Model penelitian yang digunakan adalah analisis Model Regresi Berganda dimana bertujuan untuk mengetahui pengaruh capital Intensity, profitabilitas, dan ukuran perusahaan terhadap agresivitas pajak. Uji statistik t pada dasarnya menunjukan seberapa jauh pengaruh satu variabel penjelas/independen secara individual dalam menerangkan variasi variabel dependen (Ghozali, 2018:98-99) Pengujian ini menggunakan signifikansi level 0,05 ( $\alpha=5 \%)$.

Pada penelitian ini merupakan jenis penelitian dengan pengujian hipotesis dengan analisis regresi berganda. Uji analisis regresi linear berganda dengan model regresi sebagai berikut:

$\mathrm{Y}=\alpha+\beta 1 \mathrm{X} 1+\beta 2 \mathrm{X} 2+\beta 3 \mathrm{M}+\mathrm{e}$

Untuk menguji adanya pengaruh pemoderasi dilakukan uji interaksi variabel moderasi menggunakan moderated regression analysis (MRA), dalam persamaan regresinya mengandung 
unsur interaksi (perkalian dua atau lebih variabel independen). Adapun model persamaan MRA yang digunakan dalam penelitian ini adalah sebagai berikut:

$\mathrm{Y}=\mathrm{a}+\mathrm{b} 1 \mathrm{X} 1+\mathrm{b} 2 \mathrm{X} 2+\mathrm{b} 3 \mathrm{M}+\mathrm{b} 4 \mathrm{X} 1 \times \mathrm{M}+\mathrm{b} 5 \mathrm{X} 2 \times \mathrm{M}+\mathrm{e}$

Keterangan:

$$
\begin{array}{ll}
\mathrm{Y} & =\text { Agresivitas pajak. } \\
\alpha & =\text { Konstanta. } \\
\beta 1-\beta 3 & =\text { Koefisiensi Regresi. } \\
\mathrm{X} 1, \mathrm{X} 2 & =\text { Capital intensity, profitabilitas } \\
\mathrm{X} 4(\mathrm{Z}) & =\text { Ukuran Perusahaan (variabel bebas keempat dan variabel moderasi) } \\
\mathrm{e} & =\text { Error }
\end{array}
$$

\section{HASIL DAN PEMBAHASAN}

\section{Statistik Deskriptif}

Tabel 1: Hasil Uji Statistik Deskirptif

\begin{tabular}{lrrrrr}
\hline \multicolumn{5}{c}{ Descriptive Statistic } \\
\hline N & \multicolumn{1}{c}{ Minimum } & \multicolumn{1}{c}{ Maximum } & \multicolumn{1}{c}{ Mean } & Std. Deviation \\
\hline Cl & 75 & .00 & .69 & .2566 & .18659 \\
ROA & 75 & -.13 & .21 & .0427 & .07201 \\
ETR & 75 & -.73 & .07 & -.2699 & .16428 \\
SIZE & 75 & 25.72 & 32.26 & 29.4921 & 1.54948 \\
Valid N (listwise) & 75 & & & & \\
\hline
\end{tabular}

Sumber: Output SPSS 25

Sesuai dengan Tabel 1 terlihat bahwa total observasi data yang diolah didalam penelitian ini berjumlah 75 observasi sepanjang periode penelitian tahun 2016-2018. Agresivitas pajak terendah adalah -0,7268 sedangkan Agresivitas Pajak tertinggi mencapai 0,0716. Secara keseluruhan agresivitas pajak memiliki rata rata $-0,2699$ pada perusahaan pertambangan di Bursa Efek Indonesia. Nilai rata - rata dari agresivitas pajak bertanda negative mengindikasikan bahwa banyaknya perusahaan sampel yang mengalami kerugian.

Variabel Capital Intensity, dapat digambarkan bahwa nilai Capital Intensity terendah yang dimiliki salah satu perusahaan yang dijadikan sampel mencapai 0,0012 sedangkan nilai Capital Intensity tertingginya adalah sebesar 0,6886. Secara keseluruhan nilai rata rata Capital Intensity yang dimiliki pada umumnya perusahaan go public di Bursa Efek Indonesia adalah 0,2566. Hal ini menunjukkan bahwa sekitar $25,66 \%$ asset yang dimiliki oleh perusahaan sampel berupa asset tetap.

Variabel Profitabilitas, dapat digambarkan bahwa nilai Profitabilitas terendah yang dimiliki salah satu perusahaan go public di Bursa Efek Indonesia yang dijadikan sampel -0,1349 sedangkan nilai Profitabilitas tertinggi yang dimiliki salah satu perusahaan go public di Bursa Efek Indonesia adalah 0,21. Secara keseluruhan nilai rata - rata 
profitabilitas yang dimiliki pada umumnya perusahaan go public di Bursa Efek Indonesia adalah 0,0427 .

Variabel Ukuran Perusahaan dapat digambarkan bahwa nilai Ukuran Perusahaan terendah yang dimiliki salah satu perusahaan go public di Bursa Efek Indonesia yang dijadikan sampel mencapai 25,7222 sedangkan nilai Ukuran Perusahaan tertinggi yang dimiliki salah satu perusahaan go public di Bursa Efek Indonesia adalah 33,2584. Secara keseluruhan nilai Ukuran Perusahaan rata rata yang dimiliki pada umumnya perusahaan go public di Bursa Efek Indonesia adalah 29,4021 dengan standar deviasi sebesar 1,5494.

\section{Uji Kelayakan Model}

\section{Uji Koefisien Determinasi $\left(\mathbf{R}^{\mathbf{2}}\right)$}

Koefisien determinasi (R2) digunakan untuk mengukur kemampuan variable independen dalam menjelaskan variasi perubahan variable dependen. Hasil uji koefisien determinasi dalam penelitian ini dapat ditunjukkan pada tabel dibawah ini:

Tabel 2. Hasil Uji Koefisien Determinasi

\begin{tabular}{ll}
\hline Model & Adjusted $R$ Square \\
\hline Tanpa Variabel Moderasi & $0,166 \rightarrow 16,6 \%$ \\
\hline Dengan Variabel Moderasi & $0,153 \rightarrow 15,3 \%$ \\
\hline
\end{tabular}

Sumber: Data diolah. SPSS 25

Hasil uji koefisien determinasi pada table 2 diatas diketahui bahwa nilai Adjusted $\mathrm{R}$ Square tanpa variable moderasi sebesar 16,6\% hal ini menunjukan bahwa variasi Agresivitas Pajak dapat dijelaskan oleh variasi Capital Intensity, Profitabilitas dan Ukuran Perusahaan dari sebesar 16,6\%. Sedangkan sisanya sebesar 83,4\% (100\%-16,6\%) dijelaskan atau dipengaruhi oleh faktor-faktor lain yang tidak diteliti dalam penelitian ini.

Hasil uji koefisien determinasi dengan melibatkan pemoderasi seperti pada tabel 6 diatas diketahui bahwa nilai Adjusted R Square sebesar 15,3\%, dimana hasil tersebut lebih kecil dibandingkan nilai Adjusted R Square pada tabel 6 yang tidak melibatkan pemoderasi. Dengan kata lain hal tersebut menunjukan bahwa variabel ukuran perusahaan sebagai pemoderasi memperlemah pengaruh Capital Intensity dan profitabilitas terhadap Agresivitas Pajak.

\section{Hasil Uji Signifikansi Simultan ANOVA (Uji F)}

Tabel 3. Hasil Uji Signifikansi Simultan ANOVA (UJI F)

\begin{tabular}{cccc}
\hline Model & F-statistik & Signifikansi & Keterangan \\
\hline Tanpa Variabel Moderasi & 5.842 & 0,001 & Fit-model \\
Dengan Variabel Moderasi & 3.629 & 0,004 & Fit-model \\
\hline
\end{tabular}

Sumber: Data diolah. SPSS 25 
Berdasarkan table 3, Dari hasil uji ANOVA atau $\mathrm{F}$ test pada tabel 8. menunjukkan bahwa nilai $F$ hitung sebesar 5,842 dengan probabilitas $0,001<0,05$ hasil tersebut dapat diartikan bahwa Capital Intensity, Profitabilitas dan Ukuran Perusahaan secara simultan berpengaruh terhadap Agresivitas Pajak.

Berdasarkan table 3, model penelitian tersebut melibatkan variabel moderasi diketahui bahwa nilai $\mathrm{F}$ hitung sebesar 3,629 dengan probabilitas 0,004 $<0,05$ maka hal ini mengindikasikan bahwa model dengan adanya varaibel moderasi juga fit.

\section{Uji Signifikansi Parameter Individual (Uji t)}

Tabel 4. Hasil Uji Parsial Tanpa Moderasi

\begin{tabular}{lcccc}
\hline \multicolumn{1}{c}{ Variabel } & Coefficient & Std. Eror & Sigifikansi & Hasil \\
\hline Konstanta & 0.609 & 0.287 & 0.037 & \\
Capital Intensity & -0.240 & 0.118 & 0.046 & $\mathrm{H}_{1}$ Diterima \\
Profitabilitas & -0.087 & 0.037 & 0.737 & $\mathrm{H}_{2}$ Ditolak \\
Ukuran Perusahaan & -0.036 & 0.300 & 0.013 & $\mathrm{H}_{3}$ Diterima \\
\hline
\end{tabular}

Sumber: Data diolah. SPSS 25

Capital Intensity memiliki nilai t hitung sebesar -2,033 dengan probabilitas signifikansi 0,046 . Hal ini menunjukan probabilitas signifikansi lebih kecil dari taraf signifikansi $\alpha=0,05$ $(0,046<0,05)$. Maka hal ini menunjukan H1 diterima, yang berarti bahwa secara parsial variable Capital Intensity berpengaruh terhadap Agresivitas Pajak.

Profitabilitas (ROA) memiliki nilai thitung sebesar -0,337 dengan probabilitas signifikansi 0,737. Hal ini menunjukan bahwa probabilitas signifikansi lebih besar dari taraf signifikansi $\alpha=0,05(0,737>0,05)$. Maka hal ini menunjukan H2 ditolak, dimana berdasarkan hasil ini bahwa Profitabilitas yang di proksikan menggunakan ROA tidak berpegaruh terhadap Agresivitas Pajak.

Ukuran Perusahaan (Size) memiliki nilai t hitung sebesar -2,553 dengan probabilitas signifikansi 0,013 . Hal ini menunjukan bahwa probabilitas signifikansi lebih besar dari taraf signifikansi $\alpha=0,05(0,013>0,05)$. Maka hal ini menunjukan H3 diterima, yaitu variable Ukuran Perusahaan (Size) berpegaruh terhadap Agresivitas Pajak.

\section{Moderated Regression Analysis (MRA)}

MRA merupakan aplikasi khusus regresi linier berganda, dalam persamaan regresinya mengandung unsur interaksi (perkalian dua atau leih variabel independen). Uji interaksi ini digunakan untuk mengetahui sejauh mana hubungan variabel Ukuran Perusahaan dapat mempengaruhi hubungan Capital Intensity dan Profitabilitas terhadap Agresivitas Pajak. 
Tabel 5. Hasil Uji Parsial Tanpa Moderasi

\begin{tabular}{lcccc}
\hline \multicolumn{1}{c}{ Variabel } & Coefficient & Std. Eror & Sigifikansi & Hasil \\
\hline Konstanta & -0.118 & 0.029 & 0.000 & \\
Capital Intensity*Size & -0.012 & 0.004 & 0.002 & H1 Diterima \\
Profitabilitas*Size & -0.008 & 0.009 & 0.364 & H2 Ditolak \\
\hline
\end{tabular}

Sumber: Data diolah. SPSS 25

Berdasarkan hasil uji t pada table 5 diatas, dapat disimpulkan bahwa interaksi Ukuran Perusahaan dengan Capital Intensity memiliki nilai t hitung sebesar -3,287 dengan probabilitas signifikansinya sebesar 0,002 . Hal ini menunjukan bahwa probabilitas signifikansi lebih kecil dari taraf signifikansi $\alpha=0,05(0,002<0,05)$. Hal ini menunjukan bahwaUkuran Perusahaan mampu memperkuat hubungan variabel Capital Intensity terhadap Agresivitas Pajak. Begitu juga dapat disimpulkan bahwa variabel ukuran perusahaan merupakan variabel moderasi (Quasi Moderator) dimana variabel ukuran perusahaan dapat memoderasi hubungan antara variabel independen dengan variabel dependen sehingga $\mathrm{H}_{4}$ diterima.

Interaksi Ukuran Perusahaan dengan Profitabilitas memiliki nilai t hitung sebesar -0,914 dengan probabilitas signifikansinya sebesar 0,364 . Hal ini menunjukan bahwa probabilitas signifikansi lebih besar dari taraf signifikansi $\alpha=0,05(0,364>0,05)$. Hal inidapat disimpulkan bahwa variabel ukuran perusahaan merupakan variabel moderasi (Pure Moderator) dimana variabel ukuran perusahaan tidak dapat memoderasi hubungan antara variabel independen dengan variabel. Dengan kata lain $\mathrm{H}_{5}$ ditolak, Ukuran Perusahaan tidak mampu memoderasi hubungan variabel Profitablitas terhadap Agresivitas Pajak.

\section{Hasil Uji Analisis Regresi Linear Berganda}

Dalam penelitian ini menggunakan analisis regresi berganda dan Moderated Regression Analysis (MRA) untuk menguji hipotesis. Analisis regresi linear berganda merupakan alat ukur mengenai pengaruh yang terjadi antara variable dependen (terikat) dengan dua atau lebih variable independen (bebas).

Hipotesis pertama, kedua dan ketiga menggunakan analisis regresi berganda untuk mengetahui pengaruh antara variabel independen yaitu Capital Intensity, Profitabilitas dan Ukuran Perusahaan terhadap variabel dependen yaitu Agresivitas Pajak.

Pada hipotesis keempat dan kelima menggunakan Moderated Regression Analysis (MRA) untuk mengetahui pengaruh variabelindependen Capital Intensity danProfitabilitas terhadap variabeldependen yaitu Agresivitas Pajak dengan Ukuran Perusahaan sebagai variabel moderasi.

Berdasakan table 4 di atas dapat diketahui persamaan regresi sebagai berikut:

ETR $=\mathbf{a}+$ b1.CI + b2.ROA + b3.Size $+\mathrm{e}$

ETR $=0,609-0,240-0,087-0,36+e$

Dengan:

ETR = Effective Tax Rate sebagai proksi dari Agresivitas Pajak

SIZE = Size sebagai proksi dari Ukuran Perusahaan

$\mathrm{CI} \quad=$ Capital Intensity

ROA = Return On Asset (ROA) sebagai proksi dari Profitabilitas 
Konstanta sebesar 0,609 menyatakan bahwa jika variable independen dianggap konstan, maka variabel dependen nilai sama dengan konstantanya. Dengan kata lain jika, Capital Intensity, Profitabilitas dan Ukuran Perusahaan bernilai 0, maka Agresivitas Pajak nilainya adalah sebesar 60,9\%. Koefisien Capital Intensity sebesar -0,240 hal ini menunjukan bahwa setiap peningkatan 1\% dari Capital Intensity, maka akan menurunkan Agresivitas Pajak sebesar 24\% dengan asumsi variabel lainnya dianggap konstan. Koefisien Profitabilitas adalah sebesar $-0,087$ ini menunjukan bahwa setiap peningkatan $1 \%$ dari profitabilitas, maka akan menurunkan agresivitas pajak sebesar 8,7\% dengan asumsi variabel lainnya dianggap konstan. Koefisien Ukuran Perusahaan adalah sebesar -0,036 hal ini menunjukan bahwa setiap peningkatan 1\% dari Ukuran Perusahaan, maka akan menurunkan Agresivitas Pajak perusahaan sebesar 3,6\% dengan asumsi variabel lainnya dianggap konstan.

Berdasarkan tabel 5 maka dapat dihasilkan persamaan regresi MRA dalam penelitian ini adalah:

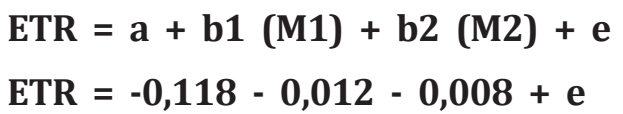

Hasil interaksi Capital Intensity dengan Ukuran Perusahaan memiliki nilai koefisien regresi sebesar -0,012 dan nilai signifikan 0,002 atau lebih kecil dari 0,05 maka dapat disimpulkan bahwa Ukuran Perusahaan mampu memoderasi hubungan Capital Intensity terhadap Agresivitas Pajak. Sedangkan hasil interaksi Profitabilitas dengan Ukuran Perusahaan memiliki nilai koefisien regresi sebesar $-0,008$ dan nilai signifikan 0,364 atau lebih besar dari 0,05 maka dapat disimpulkan bahwa Ukuran Perusahaan tidak mampu memoderasi hubungan Capital Intensity terhadap Agresivitas Pajak.

\section{PEMBAHASAN}

\section{Pengaruh Capital Intensity terhadap Agresivitas Pajak}

Hasil dari penelitian ini menyatakan bahwa secara parsial variabel capital intensity berpengaruh negatif terhadap agresivitas pajak. Ini membuktikan bahwa agresivitas pajak yang dilakukan oleh perusahaan dapat dipengaruhi oleh tingkat capital intensity-nya. Semakin besar intensitas aset tetap yang dimiliki perusahaan dapat dimanfaatkan perusahaan tersebut untuk mengurangi laba kena pajaknya, dengan memanfaatkan beban penyusutan yang timbul dari adanya aset tetap tersebut untuk mengurangi laba kena pajaknya di akhir periode sehingga dapat menurunkan beban pajak yang harus dibayarkannya. Oleh karena itu, perusahaan dengan intensitas aset tetap yang tinggi cenderung akan mengurangi agresivitas pajaknya.

Hasil penelitian ini mendukung penelitian yang dilakukan oleh (Isnanto et al., 2019), (Andhari, P. A. S., \& Sukartha, 2017), (Natalya, 2018) \& (Fachrina Yuliana, 2018) yang menyatakan bahwa Capital Intensity berpengaruh terhadap Agresivitas Pajak. Namun hasil penelitian ini tidak sejalan dengan hasil penelitian yang dilakukan oleh (Maulana, Marwa, \& Wahyudi, 2018), (Fajar Adisamartha \& Noviari, 2015) \& (Windaswari \& Merkusiwati, 2018) yang menyatakan bahwa Capital Intensity tidak memiliki pengaruh signifikan terhadap Agresivitas Pajak. 


\section{Pengaruh Profitabilitas terhadap Agresivitas Pajak}

Hasil penelitian ini menyatakan bahwa variabel profitabilitas (ROA) tidak berpegaruh signifikan terhadap agresivitas pajak. Berdasarkan teori Gone, fraud dapat terjadi diantaranya disebabkan karena adanya kesempatan dan tumpulnya penegakan hukum bagi pelaku. Oleh sebab itu perusahaan dengan tingkat profitabilitas tinggi maupun rendah memiliki peluang yang sama untuk melakukan agresivitas pajak selama masih adanya celah-celah di dalam peraturan perpajakan yang dapat dimanfaatkannya, serta hukuman bagi pelaku fraud tersebut yang tidak menimbulkan efek jera.

Hasil penelitian ni sejalan dengan hasil penelitian yang dilakukan oleh (Fachrina Yuliana, 2018), (Mustika, Ratnawati, \& Silfi, 2017), (Nugraha \& Meiranto, 2015) \& (Isnanto et al., 2019) yang menyatakan bahwa Profitabilitas tidak memiliki pengaruh signifikan terhadap Agresivitas Pajak. Namun hasil penelitian ini bertentangan dengan hasil penelitian (Windaswari \& Merkusiwati, 2018), (Sufia, Riswandari, \& Mulia, 2018) \& (Windaswari \& Merkusiwati, 2018) yang menyatakan bahwa Profitabilitas berpengaruh terhadap Agresivitas Pajak.

\section{Pengaruh Ukuran Perusahaan terhadap Agresivitas Pajak}

Hasil penelitian ini menyatakan bahwa variabel ukuran perusahaan berpegaruh negatif terhadap agresivitas pajak. Ini menunjukkan bahwa semakin besar ukuran perusahaan akan menurunkan tingkat agresivitas pajak dan memiliki pengaruh yang signifikan. Tingginya biaya penyusutan yang ditanggung perusahaan atas kepemilikan aset yang ada menyebabkan rendahnya laba perusahaan pada periode tersebut. Rendahnya laba perusahaan akan mengakibatkan rendahnya beban pajak yang harus ditanggung perusahaan pada periode tersebut, sehingga perusahaan cenderung mengurangi tindakan agresivitas pajaknya.

Selain itu, dengan semakin besarnya ukuran perusahaan maka perhatian fiskus maupun investor juga akan semakin besar terhadap perusahaan tersebut, dimana hal tersebut akan menyebabkan perusahaan tersebut akan cenderung mengurangi agresivitas pajaknya dan lebih taat terhadap peraturan yang berlaku untuk menghindari sanksi perpajakan.

Hasil penelitian ini sejalan dengan yang dilakukan oleh (Tiaras \& Wijaya, 2017), (Yanti \& Hartono, 2019) dan (Fachrina Yuliana, 2018) yang menyatakan bahwa Ukuran Perusahaan berpengaruh signifikan terhadap Agresivitas Pajak. Namun bertentangan dengan hasil penelitian yang dilakukan oleh (Windaswari \& Merkusiwati, 2018), (Mustika et al., 2017) dan (Susanto et al., 2018) yang menyatakan bahwa Ukuran Perusahaan tidak memiliki pengaruh signifikan terhadap Agresivitas Pajak..

\section{Ukuran Perusahaan memperkuat hubungan Capital Intensity terhadap Agresivitas Pajak}

Hasil penelitian ini menunjukan bahwa ukuran perusahaan memperkuat atau memoderasi hubungan Capital Intensity terhadap agresivitas pajak pada perusahaan pertambangan yang terdaftar di Bursa Efek Indonesia pada tahun 2016-2018. Hasil ini menunjukan bahwa semakin besar sebuah perusahaan maka intensitas modal dan aset yang dimilikinya akan semakin besar. 
Dengan adanya sumber daya yang besar tersebut dapat dimanfaatkan perusahaan untuk mengurangi beban pajaknya. Namun dengan semakin besarnya ukuran sebuah perusahaan yang ditunjukan dari besarnya nilai aset yang dimilikinya maka perusahaan tersebut akan mendapatkan perhatian lebih dari pemerintah maupun investor. Oleh sebab itu, semakin besar ukuran perusahaan dengan intensitas modal yang juga tinggi cenderung akan mengurangi tindakan agresivitas pajaknya.

Hasil penelitian ini sejalan dengan penelitian (Tiaras \& Wijaya, 2017), (Yanti \& Hartono, 2019) dan (Fachrina Yuliana, 2018) yang menyatakan bahwa Ukuran Perusahaan berpengaruh signifikan terhadap Agresivitas Pajak. Namun bertentangan dengan hasil penelitian yang dilakukan oleh (Windaswari \& Merkusiwati, 2018), (Mustika et al., 2017) dan (Susanto et al., 2018) yang menyatakan bahwa ukuran perusahaan tidak memiliki pengaruh signifikan terhadap agresivitas pajak. Serta bertentangan pula dengan penelitian yang dilakukan oleh (Maulana et al., 2018) dimana dalam penelitiannya menyatakan bahwa ukuran perusahaan tidak dapat memoderasi hubungan capital intensity terhadap agresivitas pajak.

\section{Ukuran Perusahaan memperkuat hubungan Capital Intensity terhadap Agresivitas Pajak}

Hasil penelitian ini menunjukan bahwa ukuran perusahaan memperlemah atau tidak dapat memoderasi hubungan variabel profitablitas terhadap agresivitas pajak. Kondisi tersebut mengindikasikan bahwa dengan semakin besarnya ukuran perusahaan akan mengurangi agresivitas pajak pada perusahaan tersebut, meskipun memiliki nilai profiabilitas yang tinggi sekalipun. Hal tersebut disebabkan karena berdasarkan teori biaya politik perusahaan besar cenderung akan mendapat pengawasan lebih dari pemerintah untuk dikenakan pembayaran pajak yang sesuai dengan peraturan perpajakan yang berlaku.

Hasil penelitian mendukung teori biaya politik dimana pada teori tersebut dijelaskan bahwa dengan adanya perhatian pemerintah pada perusahaan besar maka tindakan penghindaran pajak akan terminimalisir. Hasil ini mendukung penelitan (Putra \& Jati, 2018) \& (Fitri \& Munandar, 2018) yang menyatakan bahwa Ukuran Perusahaan memperlemah hubungan antara Profitabilitas dengan Agresivitas Pajak. Namun hasil ini bertentangan dengan hasil penelitian yang dilakukan oleh (Windaswari \& Merkusiwati, 2018), (Mustika et al., 2017) dan (Susanto et al., 2018) yang menyatakan bahwa Ukuran Perusahaan tidak memiliki pengaruh signifikan terhadap Agresivitas Pajak.

\section{SIMPULAN}

Berdasarkan hasil dari pengujian hipotesis dapat disimpulkan dalam penelitian ini yaitu: (1) Capital intensity berpengaruh negatif terhadap agresivitas pajak; (2) Profitabilitas tidak berpengaruh terhadap agresivitas ajak; (3) Ukuran perusahaan berpengaruh negatif terhadap agresivitas pajak; (4) Ukuran perusahaan memperkuat pengaruh antara capital intensity terhadap agresivitas pajak; (5) Ukuran perusahaan memperlemah hubungan antara profitabilitas terhadap agresivitas pajak. Penelitian ini masih memiliki beberapa kelemahan seperti jumlah data observasi yang digunakan tergolong pendek. Oleh karena itu, peneliti 
selanjutnya disarankan untuk memperpanjang periode observasi. Selain itu, peneliti selanjutnya dapat menggunakan pengukuran agresivitas yang lain seperti cash ETR, book tax gap dan lainnya.

\section{PUSTAKA ACUAN}

Andhari, P. A. S., \& Sukartha, I. M. (2017). E-Jurnal Akuntansi Universitas Udayana Pengaruh Pengungkapan Corporate Social Responsibility, Profitabilitas, Inventory Intensity, Capital Intensity dan Leverage pada Agresivitas Pajak. Udayana, E-Jurnal Akuntansi Universitas, 18(2017), 2115-2142.

Crocker, K. J., \& Slemrod, J. (2004). Corporate Tax Evasion with Agency Costs. (August). Retrieved from http://www.nber.org/papers/w10690

Fachrina Yuliana, I. (2018). Likuiditas, Profitabilitas, Leverage, Ukuran Perusahaan Capital Intensity, dan Inventory Intensity terhadap Agresivitas Pajak. Foreign Affairs, 7(2), 105-120. https://doi.org/10.1017/CB09781107415324.004

Fajar Adisamartha, I., \& Noviari, N. (2015). Pengaruh Likuiditas, Leverage, Intensitas Persediaan Dan Intensitas Aset Tetap Pada Tingkat Agresivitas Wajib Pajak Badan. E-Jurnal Akuntansi, 13(3), 973-1000.

Finance.detik.com. (2019). Berita Adaro - finance.detik.pdf.

Fitri, R. A., \& Munandar, A. (2018). The Effect of Corporate Social Responsibility, Profitability, and Leverage toward Tax Aggressiveness with Size of Company as Moderating Variable. Binus Business Review, 9(1), 63. https://doi.org/10.21512/ bbr.v9i1.3672

Ghozali, Imam. 2013. Aplikasi Analisis Multivariate dengan Program SPSS. Edisi Ketujuh. Semarang: Badan Penerbit Universitas Diponegoro.

Hartono, Jogiyanto. 2015. Teori Portfolio dan analisis invenstasi edisi kesepuluh. Yogyakarta: BPFE.

Harahap, Sofyan Syafri, 2015. Analisis Kritis atas Laporan Keuangan. Edisi 1. Jakarta: Rajawali Pers.

Hanlon, M., \& Heitzman, S. (2010). A review of tax research. Journal of Accounting and Economics, 50(2-3), 127-178. https://doi.org/10.1016/j.jacceco.2010.09.002

Isgiyata, J., Indayani, I., \& Budiyoni, E. (2018). Studi Tentang Teori GONE dan Pengaruhnya Terhadap Fraud Dengan Idealisme Pimpinan Sebagai Variabel Moderasi: Studi Pada Pengadaan Barang/Jasa di Pemerintahan. Jurnal Dinamika Akuntansi Dan Bisnis, 5(1), 31-42. https://doi.org/10.24815/jdab.v5i1.8253

Isnanto, H. D., Si, M., \& Ab, S. (2019). Pengaruh Intensitas Modal, Intensitas Persediaan, Profitabilitas dan Kompensasi rugi Fiskal terhadap Agresivitas Pajak. 6(2), 3257-3264.

Liputan6.com. (2019). Berita Adaro - Liputan6.com.pdf.

Margaret, M., Lynch, L. J., Rego, S. O., \& Rego, S. O. (2009). Tax Reporting Aggressiveness to Aggressive and Its Relation Financial Reporting University of Virginia. Accounting Review, 84(2), 467-496. 
Maulana, Marwa, T., \& Wahyudi, T. (2018). The Effect of Transfer Pricing, Capital Intensity and Financial Distress on Tax Avoidance with Firm Size as Moderating Variables. Modern Economics, 11(1), 122-128. https://doi.org/10.31521/modecon.v11(2018)-20

Mustika, Ratnawati, V., \& Silfi, A. (2017). Pengaruh Corporate Social Responsibility, Ukuran Perusahaan, Profitabilitas, Leverage, Capital Intensity dan Kepemilikan Keluarga terhadap Agresivitas Pajak (Studi Empiris pada Perusahaan Pertambangan dan Pertanian yang Terdaftar di Bursa Efek Indonesia P. Jurnal Online Mahasiswa Fakultas Ekonomi Universitas Riau, 4(1), 1886-1900.

Natalya, D. (2018). Pengaruh Capital Intensity, Leverage dan Profitabilitas Terhadap Tax Agresivitas dengan Kinerja Pasar sebagai Variabel Moderating. Media Akuntansi Perpajakan, 3(1), 37-55.

Novitasari, S., Vince, P., \& Silfi, A. (2017). Pengaruh manajemen Laba, Corporate Governance dan Intensitas Modal tehadap Agresivitas Pajak. 4(1).

Nugraha, N. B., \& Meiranto, W. (2015). Pengaruh Corporate Social Responsbility, Ukuran Perusahaan, Profitabilitas, Leverage dan Capital Intensity terhadap Agresivitas Pajak. 4(4), 564-577. Retrieved from http://ejournal-s1.undip.ac.id/index.php/accounting

Putra, N. T., \& Jati, I. K. (2018). Ukuran Perusahaan Sebagai Variabel Pemoderasi Pengaruh Profitabilitas pada Penghindaran Pajak. E-Jurnal Akuntansi, 25, 1234. https://doi. org/10.24843/eja.2018.v25.i02.p16

Richardson, G., Taylor, G., \& Lanis, R. (2013). The impact of board of director oversight characteristics on corporate tax aggressiveness: An empirical analysis. Journal of Accounting and Public Policy, 32(3), 68-88. https://doi.org/10.1016/j.jaccpubpol.2013.02.004

Ridha, M., \& Martani, D. (2014). Analisis terhadap Agresivitas Pajak, Agresivitas Pelaporan Keuangan, Kepemilikan Keluarga, dan Tata Kelola Perusahaan di Indonesia.

Sari, D. K. dan D. M. (2010). Ownership Characteristics,Corporate Governance and Tax Aggressiveness. Bridging the Gap between Theory,Research and Practice:IFRS Convergence and Application, 1-33. Retrieved from http://staff.ui.ac.id/system/files/users/martani/ publication/tax-03ownershipcharacteristicscorporategove-dewikartikasaridwimartani.pdf

Sufia, L., Riswandari, E., \& Mulia, U. B. (2018). Pengaruh Manajemen Laba, proporsi Komisaris dan Likuiditas terhadap Tax Agresivitas. 11(2), 140-156.

Suprasto, N. P. D., \& Suprimarini, B. (2017). Pengaruh Corporate Social Responsibility, Kualitas Audit, Dan Kepemilikan Institusional Pada Agresivitas Pajak. E-Jurnal Akuntansi Universitas Udayana, 19, 1349-1377.

Susanto, L., Yanti, Y., \& Viriany, V. (2018). Faktor-faktor yang mempengaruhi agresivitas pajak. Jurnal Ekonomi, 23(1), 10-19. https://doi.org/10.24912/je.v23i1.330

Tiaras, I., \& Wijaya, H. (2017). Pengaruh Likuiditas, Leverage, Manajemen Laba, Komisaris Independen Dan Ukuran Perusahaan Terhadap Agresivitas Pajak. Jurnal Akuntansi, 19(3), 380. https://doi.org/10.24912/ja.v19i3.87

Windaswari, K. A., \& Merkusiwati, N. K. L. A. (2018). Pengaruh Koneksi Politik, Capital Intensity, Profitabilitas, Leverage dan Ukuran Perusahaan Pada Agresivitas Pajak. E-Jurnal Akuntansi, 23, 1980. https://doi.org/10.24843/eja.2018.v23.i03.p14 
Yanti, L. D., \& Hartono, L. (2019). Effect of Leverage, Profitability and Company Size on Tax Aggressiveness. (Empirical Study: Subsector Manufacturing Companies Food, Beverage, Cosmetics and Household Purposes Manufacturing Listed on the Indonesia Stock Exchange for. 1(1). 